\title{
FOLIAR NUTRIENT CONCENTRATIONS AND HARDWOOD GROWTH INFLUENCED BY CULTURAL TREATMENTS
}

\author{
by HARVEY E. KENNEDY, JR. \\ Southern Hardwoods Laboratory, U.S. Forest Service, Stoneville, \\ Mississippi 38776, USA
}

\begin{abstract}
KEY WORDS
Carya illinoensis Clean cultivation Disking Fraxinus pennsylvanica Liquidambar styraciflua Platanus occidentalis Populus deltoides Quercus nuttallii Sharkey clay
\end{abstract}

\section{SUMMARY}

Six species of hardwoods were planted at a 3 by $3 \mathrm{~m}$ spacing on a slackwater clay soil (Vertic Haplaquept) in western Mississippi and subjected to three intensities of cultural treatments. Periodic disking significantly increased heights, diameters, and survival of trees. Cultural treatments during the 4 years of the study did not cause any significant changes in soil nutrient levels. Disking eliminated vines and weeds and thus made more water available to trees.

Trees growing on disked plots had significantly higher $\mathrm{N}$ and $\mathrm{Ca}$ and significantly lower $\mathrm{P}$ and $\mathrm{Mg}$ concentrations in foliage than trees in mowed and control plots. Trees in mowed plots had signifcantly lower $\mathrm{K}$ than control plots, while disked plots had $\mathrm{K}$ concentrations that were intermediate between mowed and control. Cottonwood had the highest nutrient concentrations and sycamore the lowest for most elements tested. Other species were intermediate, and no ranking was apparent.

\section{INTRODUCTION}

Most hardwoods grown in plantations are intolerant, and sites must be intensively cultivated to eliminate competition from weeds, vines, and grasses. However, quantitative data on the effects of intensity and duration of cultural treatments in plantations on soil nutrient availability and uptake, soil moisture, tree growth, and survival is lacking. Nevertheless, more and more forest managers are practicing intensive plantation management of hardwoods because of the demand for quality logs for veneer, lumber, and specialties, and the expanding use of hardwoods for pulp and fuel. This paper reports on soil and foliar nutrient levels, soil moisture, and growth and survival of six hardwoods as influenced by three intensities of cultural treatment: uncultivated, mowed, and disked. 


\section{METHODS}

The plantation occupied about 4 ha on the Delta Experimental Forest near Stoneville, Mississippi. The site recently had been cleared of a natural mixed hardwood stand and prepared for planting by shearing, root raking, and disking. Soil is Sharkey clay, a member of the montmorillonitic, thermic family of Vertic Haplaquepts.

A split-split-plot design was used. Blocks (.67 ha) were split into three equal-sized plots. One of three cultural treatments, control (no treatment), mow, or cross disking (clean cultivation) was randomly assigned to a plot. Plots were divided into six subplots with one species randomly assigned to a subplot. The species were cottonwood (Populus deltoides Bartr. ex Marsh.), sycamore (Platanus occidentalis L.), green ash (Fraxinus pennsylvanica Marsh.), sweetgum (Liquidambar styraciflua L.), Nuttall oak (Quercus nuttallii Palmer), and sweet pecan (Carya illinoensis (Wangenh.) K. Koch). There were six replications of each cultural treatment, and 24 one-year-old seedlings of cottonwood cuttings per plot were planted at 3 by $3 \mathrm{~m}$ spacing. Plots were disked or mowed five times at 3-4 week intervals from late April through early September the first growing season, four times the second, and three times in years 3 and 4 . In years 2,3 , and 4 plots were treated at 4-6 week intervals during the same time period.

Surface soil moisture and moisture at $0.3,0.6,0.9$, and 1.3 meters were measured on a volume basis with neutron probes. Measurements were made approximately every 2 weeks, when climatic and soil conditions permitted. Subsurface moisture readings were made using aluminum access tubes. Moisture measurements were made at one location in each cultural treatment plot; a total of 18 locations in the study area.

Soil organic matter (OM), N, P, K, Ca, Mg, and $\mathrm{pH}$ levels were determined before cultural treatments were started and at the end of each growing season. Samples from the $0-$ to $15-\mathrm{cm}$ layer were collected at five randomly located points within a cultural treatment without regard to species. Collections were made in early September each year and composited to make one sample. Collections each year were made within $0.6 \mathrm{~m}$ of the previous year's samples. Samples were air dried and processed to pass a $2-\mathrm{mm}$ sieve.

All understory vegetation from two $0.6 \mathrm{~m} \times 0.6 \mathrm{~m}$ areas in each control plot were collected each year and oven dry weights determined. Collections were made in early September and N, P, K, Ca, and $\mathrm{Mg}$ concentrations determined from composite samples.

Leaf samples were collected at the mid-crown position in the crown length from each tree in a subplot in early September each year. Concentrations of $\mathrm{N}, \mathrm{P}, \mathrm{K}, \mathrm{Ca}$, and $\mathrm{Mg}$ were determined. Samples were collected at mid-crown to maintain uniformity in collections.

All tree and vegetation tissue was dried at $70^{\circ} \mathrm{C}$ and ground before chemical analyses. Nitrogen was determined by the standard Kjeldahl procedure; $\mathbf{P}$ by colorimetry with molybdenum blue color development; and $\mathrm{K}, \mathrm{Ca}$, and $\mathrm{Mg}$ by atomic absorption spectrophotometry after samples had been dry ashed and taken-up in dilute $\mathrm{HCl}$.

Soil $\mathrm{N}$ was determined by the standard Kjeldahl procedure. Phosphorus was measured with a colorimeter by the Mississippi soil test method ${ }^{10}$. Potassium, $\mathrm{Ca}$, and $\mathrm{Mg}$ concentrations were determined by atomic absorption spectrophotometry after extraction in $1 \mathrm{~N} \mathrm{NH}_{4} \mathrm{OAc}$. Soil pH was measured with a glass electrode in a $1: 1$ soil/water ratio. Oxidizable $O M$ was determined by chromic acid oxidation and titrations with $\mathrm{Fe}\left(\mathrm{NH}_{4}\right)_{2}\left(\mathrm{SO}_{4}\right)_{2}$.

Tree heights, diameters, and survival were measured after each growing season during the 4 years of the study. Diameters were measured with calipers at the root collar each year because some species did not reach $1.3 \mathrm{~m}$ heights until the second or third growing season. Diameters were also taken at breast height the fourth year. Heights were measured with an aluminum measuring pole. All statistical tests were made at the 0.05 level of probability. 


\section{RESULTS AND DISCUSSION}

\section{Tree growth and survival}

After four growing seasons, trees in disked plots were significantly taller than trees in mowed and control (Fig. 1). There were no real differences between mowed and control. Disking increased heights from $42 \%$ for green ash to $130 \%$ for sycamore over trees in control plots. In this study, trees were as tall after 2 years in disked plots as after 4 years in control plots. If we assume some of this growth advantage would remain throughout a rotation, then forest managers could reduce rotation age several years by disking during the first and maybe second growing seasons to get trees off to a good start. In 1978, it was reported that second-year cultivation had a significant influence on cottonwood growth during the second and third growing season ${ }^{1}$. These growth benefits were still evident in tree heights and diameters at the end of the fifth growing season.

Diameters at groundline in disked plots were also significantly larger than in other plots (Fig. 2). Increases ranged from $144 \%$ for cottonwood to $240 \%$ for

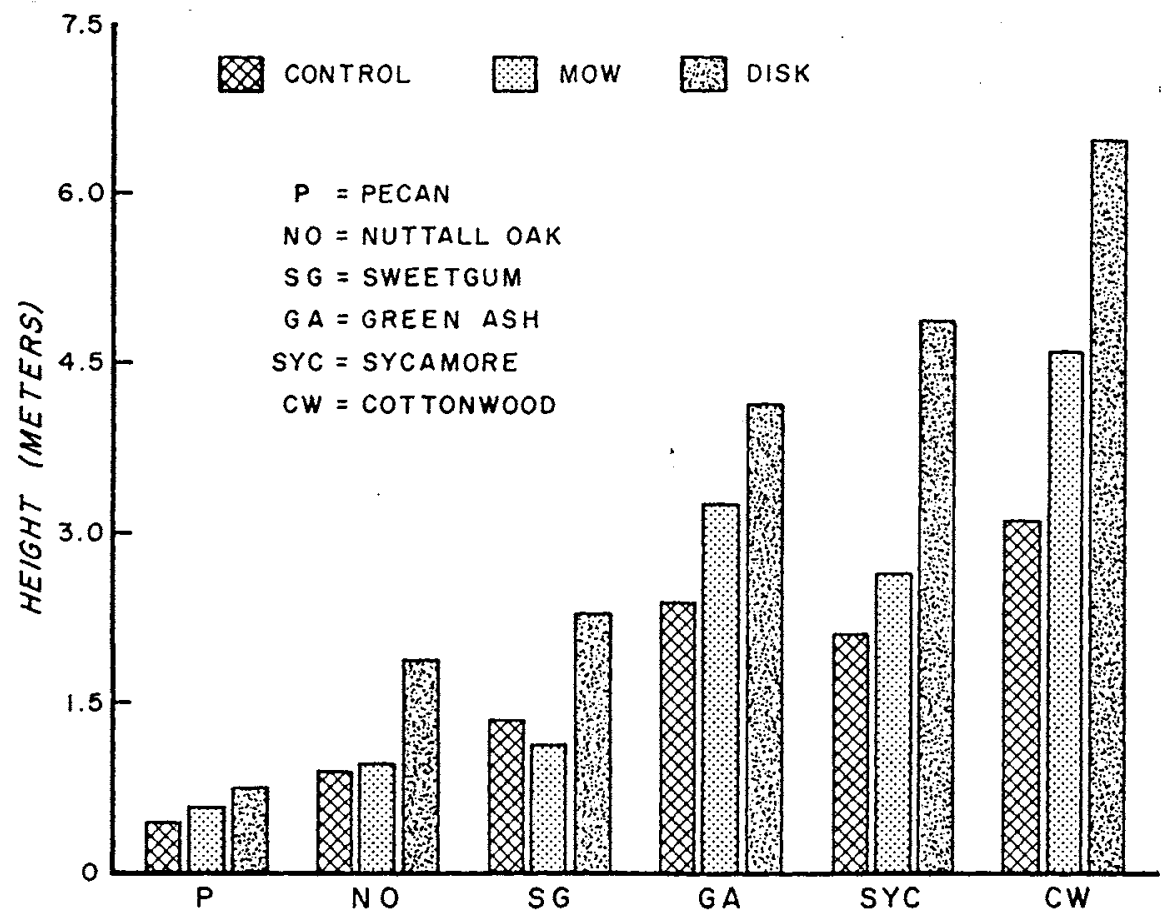

Fig. 1. Average heights by species and cultural treatment at the end of four growing seasons. 
Nuttall oak. Diameters at breast height after the fourth growing season were $55 \%$ to $60 \%$ as large as diameters at groundline.

Survival was significantly higher in disked plots $(91 \%)$ than mowed $(80 \%)$, and control $(76 \%)$. Disked plots ranged from a low of $84 \%$ survival for sweetgum to $99 \%$ for sycamore. There were no differences in survival between mowed and control plots, and survival in these plots was better than expected. Green ash survived best in mowed and control plots with sycamore a close second.

Trees and understory vegetation (weeds, vines, and grasses) compete strongly for moisture, nutrients, and sunlight. Dry weight of understory vegetation on control plots in this study averaged 13.5 metric tons per hectare per year. Nutrient concentrations in the understory vegetation were: $N, 1.13 \% ; \mathrm{P}, 0.26 \%$; $\mathrm{K}, 1.44 \%$; $\mathrm{Ca}, 0.93 \%$; and $\mathrm{Mg}, 0.24 \%$. Disking eliminated this competition, as evidenced by the much better growth in disked than in mowed and control plots (Figs. 1 and 2). Competition still exists whether weeds are allowed to grow 3 to 4 weeks and then cut back by mowing or allowed to grow continuously as in the control. Thus, mowing is not an acceptable substitute for disking.

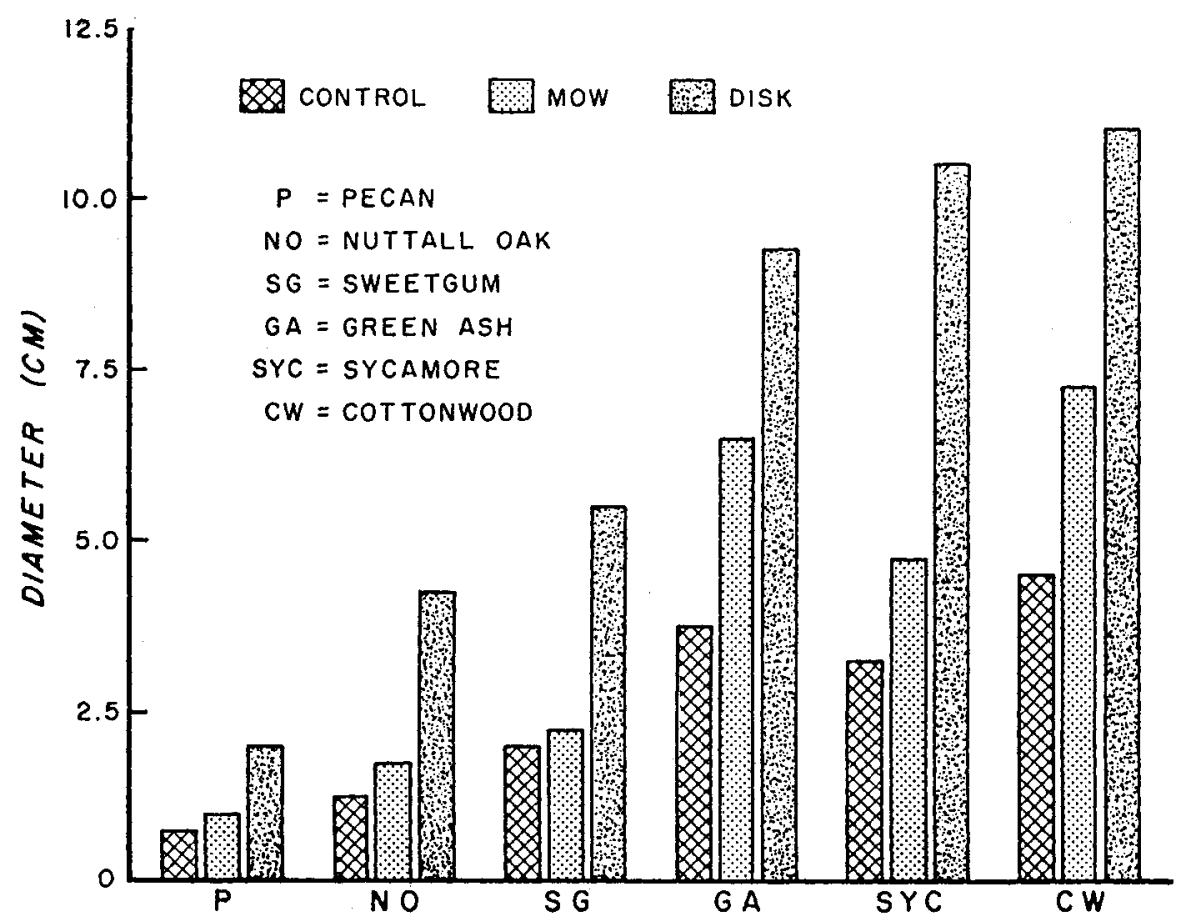

Fig. 2. Average diameters at groundline by species and cultural treatment at the end of four growing seasons. 


\section{Foliar nutrients}

For all elements, significant species by treatment interactions occurred, mainly because of inherent differences among species in nutrient uptake rather than differences caused by cultural treatments.

Cottonwood had the highest nutrient concentrations for most elements tested (Table 1). Sycamore was lowest or tied for lowest for $\mathrm{N}, \mathrm{P}$, and $\mathrm{K}$, fourth for $\mathrm{Ca}$, and third for $\mathrm{Mg}$. The other species were intermediate with no ranking really apparent. The apparent lower nutrient requirements, because sycamore had only 50 percent as much volume as cottonwood, could be a determining factor in sycamore being adapted for planting over a wide range of sites compared to the more narrow range of sites for cottonwood because of high nutrient demand.

Trees in disked plots had significantly higher $\mathbf{N}$ and $\mathrm{Ca}$ concentrations and significantly lower $\mathbf{P}$ and $\mathrm{Mg}$ than trees in the mowed and control plots (Table 1). Trees in mowed plots had significantly lower $\mathrm{K}$ than control plots, while disked plots had $\mathrm{K}$ concentrations that were intermediate between mowed and control. Although foliar concentrations were lower for some nutrients in trees in disked plots, if we assume weight to be proportional to size, then nearly twice as much of each nutrient would have been accumulated in trees in disked plots as in mowed or control plots. The higher foliar $\mathbf{N}$ levels in trees in disked plots probably resulted from reduction of competition for the available soil $\mathrm{N}$. Researchers ${ }^{2,5}$ have suggested a nitrogen foliage level of $2 \%$ to be minimum for best growth in several species of poplars. All species in this study except sycamore and green ash were above $2 \%$ foliar $\mathrm{N}$ in disked plots, but below $2 \%$ in mowed and control plots (Table 1). These data indicate the beneficial effects of disking on mineralization and also a possible $\mathrm{N}$ deficiency in mowed and control plots. Second-year cultivation has increased $\mathrm{N}$ levels in cottonwood foliage as much as an application of $200 \mathrm{lbs}$ per acre $(224 \mathrm{~kg} / \mathrm{ha})$ of $\mathrm{N}$ fertilizer ${ }^{1}$.

Over the 4 years, $P$ appeared to decrease slightly in trees in disked plots, and to increase slightly in mowed and control plots. Year to year fluctuations, however, keep these trends from being clearly defined. Tissue $\mathrm{K}$ tended to decrease each year, especially in disked plots, but was the most erratic and hardest to predict trend of all elements tested. Generally, Ca concentrations increased the first 3 years for all species, but decreased during the fourth year. $\mathrm{Mg}$ concentrations increased each year. The change from year 1 to 2 was not significant, but year 3 was significantly higher than 1 and 2 , and year 4 significantly higher than year 3 . The lower $\mathbf{P}, \mathbf{K}$, and $\mathrm{Mg}$ concentrations in trees in disked plots probably resulted from dilution with growth. 
Table 1. Average foliar nutrient concentrations in percent by species and cultural treatments over the four study years

\begin{tabular}{|c|c|c|c|c|c|c|c|c|c|c|c|c|c|c|c|}
\hline \multirow{2}{*}{ Species** } & \multicolumn{3}{|c|}{$\mathrm{N}^{*}$} & \multicolumn{3}{|c|}{$\mathbf{P}$} & \multicolumn{3}{|c|}{$\mathbf{K}$} & \multicolumn{3}{|c|}{$\mathrm{Ca}$} & \multicolumn{3}{|c|}{$\mathbf{M g}$} \\
\hline & $C^{* * *}$ & $\mathbf{M}$ & D & C & $\mathbf{M}$ & $\mathrm{D}$ & $\mathrm{C}$ & $\mathbf{M}$ & D & C & $\mathbf{M}$ & D & C & $\mathbf{M}$ & $\mathrm{D}$ \\
\hline CW & 1.74 & 1.89 & 2.09 & .19 & .18 & .17 & 1.04 & .96 & 1.12 & 2.00 & 2.16 & 2.19 & .37 & .42 & .38 \\
\hline GA & 1.67 & 1.72 & 1.87 & .30 & .29 & .20 & .81 & .75 & .69 & 1.04 & 1.27 & 1.53 & .18 & .19 & .23 \\
\hline NO & 1.65 & 1.71 & 1.94 & .16 & .14 & .14 & .68 & .69 & .67 & .79 & .75 & .71 & .21 & .18 & .16 \\
\hline SG & 1.70 & 1.70 & 2.06 & .31 & .28 & .17 & .68 & .59 & .61 & .89 & .90 & .83 & .30 & .29 & .24 \\
\hline SP & 1.84 & 1.86 & 2.02 & .17 & .16 & .15 & .63 & .61 & .58 & 1.54 & 1.54 & 1.61 & .34 & .33 & .32 \\
\hline Syc & 1.59 & 1.64 & 1.82 & .16 & .16 & .14 & .58 & .55 & .60 & 1.48 & 1.45 & 1.56 & .23 & .24 & .24 \\
\hline $\mathbf{X}$ & $\overline{1.70 \mathrm{a}}$ & $1.75 \mathrm{a}$ & $1.97 \mathrm{~b}$ & $.21 \mathrm{a}$ & $.20 \mathrm{~b}$ & $.16 \mathrm{c}$ & $.73 a$ & $.69 \mathrm{~b}$ & $.71 \mathrm{ab}$ & $1.29 \mathrm{a}$ & $1.35 \mathrm{~b}$ & $1.40 \mathrm{c}$ & $.27 \mathrm{a}$ & $.28 \mathrm{~b}$ & $.26 \mathrm{c}$ \\
\hline
\end{tabular}

* Treatment means followed by the same letter are not significantly different at the 0.05 level.

** $\mathbf{C W}=$ cottonwood, $\mathrm{GA}=$ green ash, $\mathrm{NO}=$ Nuttall oak, $\mathrm{SG}=$ sweetgum, $\mathrm{SP}=$ sweet pecan, $\mathrm{Syc}=$ sycamore.

*** $\mathrm{C}=$ control, $\mathrm{M}=$ mow, $\mathrm{D}=$ disk. 


\section{Soil nutrients}

Cultural treatments over the 4 years of this study did not cause any significant reductions in soil nutrient levels (Table 2). One of the major benefits of disking probably was competition control. However, it also improves soil structure, water infiltration and storage, gas exchange between soil and atmosphere, organic matter, nutrient availability, and root proliferation by causing branching when roots near the surface are cut.

Averaged over all cultural treatments, years significantly affected all nutrients except $\mathrm{Ca} ; \mathrm{pH}$ was not affected. Soil $\mathrm{N}, \mathrm{P}, \mathrm{K}$, and $\mathrm{OM}$ were lowest after the third growing season. Soil moisture for July, August, and September that year was also significantly lower than any of the other 3 years. Rainfall during these 3 months in 1971 was $36 \mathrm{~cm}, 26 \mathrm{~cm}$ in $1972,22 \mathrm{~cm}$ in 1973, and $33 \mathrm{~cm}$ in 1974 . Ca and pH remained relatively constant with no real differences measured during the 4 years. $\mathrm{Mg}$ dropped after the first two growing seasons, increased to its highest level during the third (the driest season), and then decreased again after the fourth growing season. These relationships between soil moisture and soil nutrient availability follow trends reported for 5-year-old cottonwood on a clay site ${ }^{6}$.

\section{Soil moisture}

Average soil moisture was highest (46.6\%) during the first growing season (1971) and lowest $(39.9 \%)$ the third growing season (1973). The second and fourth growing seasons were intermediate. Rainfall during April through September was $64 \mathrm{~cm}$ in 1971, $52 \mathrm{~cm}$ in 1972 and 1973, and $96 \mathrm{~cm}$ in 1974. These data indicate a higher moisture demand by the larger trees in the third and fourth growing seasons. Soil moisture measurements did not differ by cultural treatment on any date.

It is generally accepted that evapotranspiration in a fully stocked forest stand in the Gulf South is about $0.6 \mathrm{~cm}$ per day. Field capacity $(60-\mathrm{cm}$ moisture) has been reported for Sharkey clay to be $54 \% / \mathrm{vol}$ and wilting point (15-bar moisture) was $30 \% / \mathrm{vol}^{4}$. Research has shown that up to $50 \%$ of the moisture loss in a forest stand could be used by the understory ${ }^{11}$. In my study, moisture that was used by the weeds and grasses in the mowed and control plots was available for use by trees in the disked plots. Apparently, during the summer months even in disked plots, because of transpiration or evaporative losses, there was never more available moisture than the trees could use, since we could not measure any more moisture in disked plots than the others.

Soil moisture availability greatly influenced growth in all treatments. During 
Table 2. Soil nutrient levels by cultural treatment and years

\begin{tabular}{|c|c|c|c|c|c|}
\hline \multirow{2}{*}{$\begin{array}{l}\text { Cultural } \\
\text { treatment }\end{array}$} & \multicolumn{5}{|c|}{ Years } \\
\hline & $0^{*}$ & 1 & 2 & 3 & 4 \\
\hline & \multicolumn{5}{|c|}{$N$ - percent } \\
\hline Control & $.17^{* *}$ & .20 & .16 & .15 & .17 \\
\hline Mow & .17 & .20 & .16 & .15 & .17 \\
\hline Disk & .17 & .20 & .17 & .12 & .14 \\
\hline \multirow[t]{2}{*}{$\mathbf{X}$} & $.17 b^{* * *}$ & $.20 \mathrm{a}$ & $.16 \mathrm{~b}$ & $.14 c$ & $.16 \mathrm{~b}$ \\
\hline & \multicolumn{5}{|c|}{$P-k g / h a$} \\
\hline Control & 104 & 105 & 111 & 93 & 106 \\
\hline Mow & 106 & 115 & 103 & 92 & 107 \\
\hline Disk & 102 & 122 & 118 & 96 & 105 \\
\hline \multirow[t]{2}{*}{8} & $104 a b$ & $114 a$ & $111 \mathrm{a}$ & $94 b$ & $106 \mathrm{ab}$ \\
\hline & \multicolumn{5}{|c|}{$K-k g / h a$} \\
\hline Control & 970 & 1040 & 1000 & 920 & 1130 \\
\hline Mow & 970 & 1100 & 930 & 960 & 1060 \\
\hline Disk & 1000 & 1060 & 990 & 960 & 1100 \\
\hline \multirow[t]{2}{*}{$\overline{\mathbf{X}}$} & $980 \mathrm{~b}$ & $1060 \mathrm{a}$ & $980 \mathrm{~b}$ & $950 \mathrm{~b}$ & $1100 \mathrm{a}$ \\
\hline & \multicolumn{5}{|c|}{$\mathrm{Ca}-\mathrm{kg} / \mathrm{ha}$} \\
\hline Control & 12500 & 12700 & 12900 & 12700 & 12600 \\
\hline Mow & 12900 & 12800 & 12800 & 12800 & 12600 \\
\hline Disk & 12700 & 12900 & 12700 & 12700 & 12900 \\
\hline \multirow[t]{2}{*}{$\overline{\mathrm{X}}$} & $12700 \mathrm{a}$ & $12800 \mathrm{a}$ & $12800 \mathrm{a}$ & $12700 \mathrm{a}$ & $12700 \mathrm{a}$ \\
\hline & \multicolumn{5}{|c|}{$M g-k g / h a$} \\
\hline Control & 2990 & 2900 & 2860 & 2940 & 2930 \\
\hline Mow & 2960 & 2920 & 2890 & 2940 & 2880 \\
\hline Disk & 2950 & 2900 & 2770 & 3120 & 2940 \\
\hline $\mathrm{X}$ & $2970 a$ & $2910 \mathrm{ab}$ & $2840 \mathrm{~b}$ & $3100 a$ & $2920 \mathrm{ab}$ \\
\hline & & & $p H$ & & \\
\hline Control & 6.0 & 6.0 & 6.1 & 6.0 & 6.1 \\
\hline Mow & 6.0 & 6.0 & 6.0 & 6.0 & 6.1 \\
\hline Disk & 6.0 & 6.0 & 6.1 & 6.0 & 6.1 \\
\hline \multirow[t]{2}{*}{$\bar{X}$} & $6.0 \mathrm{a}$ & $6.0 \mathrm{a}$ & $6.1 \mathrm{a}$ & $6.0 \mathrm{a}$ & $6.1 \mathrm{a}$ \\
\hline & \multicolumn{5}{|c|}{$O . M .-$ percent } \\
\hline Control & 3.3 & 3.3 & 2.8 & 2.5 & 3.0 \\
\hline Mow & 3.7 & 3.9 & 2.7 & 2.5 & 3.1 \\
\hline Disk & 3.5 & 3.6 & 3.1 & 2.0 & 2.6 \\
\hline $\mathrm{X}$ & $3.5 \mathrm{a}$ & $3.6 \mathrm{a}$ & $2.9 \mathrm{~b}$ & $2.3 \mathrm{c}$ & $2.9 \mathrm{~b}$ \\
\hline
\end{tabular}

* Year 0 is for nutrient levels before cultural treatments began; others are after each growing season.

** Within a given year and over all nutrients, there were no significant differences between cultural treatments. *** Means for a given element followed by the same letter are not significantly different at the 0.05 level. 
the third growing season, significantly the driest, most species grew about onehalf as much as they did during the wetter years. It was reported in 1979 that, because water is involved in so many of the physiological processes in the plant, any internal water stress will profoundly affect plant growth ${ }^{9}$. As the soil approaches the permanent wilting point, the plant water stress will be largely controlled by soil moisture. Cell enlargement will virtually stop and net photosynthesis will be close to zero.

In my study, soil moisture each year started high ( $55 \%)$ and diminished during the growing season. Soil moisture was lowest (mid-30\%) in late July and remained at about this level during July and August. These data follow trends reported by others ${ }^{3,7,8}$. Thus, growth in the mowed and control plots probably had slowed greatly by late June to early July because weeds and vines as well as trees were competing for soil moisture, whereas the available moisture in disked plots was being used only by the trees.

Moisture was also depleted by depth during the growing season. Surface moisture was lowest, followed by the 0.3 -meter depth, and then 0.6-meter depth. At the lower depths $(0.9$ and $1.3 \mathrm{~m})$, soil moisture remained relatively constant during the growing season, an indication that most roots did not penetrate more than $0.6 \mathrm{~m}$ deep in the Sharkey clay soil.

\section{SUMMARY AND CONCLUSIONS}

Cottonwood had the highest nutrient concentrations and sycamore the lowest for most elements tested. The other species were intermediate with no ranking really apparent. Lower nutrient requirements could be a determining factor in sycamore being adapted for planting over a wide range of sites compared to a more narrow range for cottonwood because of high nutrient demand.

By eliminating competition, disking directly or indirectly increased nutrients and soil moisture for uptake by trees, as evidenced by their larger nutrient accumulations and better growth. Anything less than the degree of site preparation and disking used in this study results in lower survival and reduced growth. There were no significant reductions in soil nutrient levels because of cultural treatments during the study.

Received 27 April 1981

\section{REFERENCES}

1 Baker, James B. and Blackmon, B. G. 1978 Summer fallowing - a simple technique for improving old-field sites for cottonwood. U.S. Dep. Agric. For. Serv. Res. Pap. SO-142, 5 p. South. For. Exp. Stn., New Orleans, La. 
2 Blackmon, B. G. and White, E. H. 1972 Nitrogen fertilization increases cottonwood growth on old-field soil. U.S. Dep. Agric. For. Serv. Res. Note SO-143, 5 p. South. For. Exp. Stn., New Orleans, La.

3 Brewer, C. W. 1975 Rooting depth of mature loblolly pine (Pinus taeda L.) as influenced by physical properties of the soil in southeastern Louisiana. Ph.D. Thesis, La. State Univ., Baton Rouge, La. 232 p.

4 Broadfoot, Walter M. 1976 Hardwood suitability for and properties of important Midsouth soils. U.S. Dep: Agric. For. Serv. Res. Pap. SO-127, 84 p. South. For. Exp. Stn., New Orleans, La.

5 Carter, M. C. and White, E. H. 1971 Dry weight and nutrient accumulation in young stands of cottonwood (Populus deltoides Bartr.). Auburn Univ., Ala. Agric. Exp. Stn. Circ. 190, 14 p.

6 Krinard, R. M. and Kennedy, H. E. Jr. 1980 Five-year-old cottonwood plantation on a clay site: growth, yield, and soil properties. South. J. Appl. For. 4, 80-83.

7 Lorio, P. L. and Hodges, J. D. 1971 Microrelief, soil water regime, and loblolly pine growth on a wet, mounded site. Soil Sci. Soc. Am. Proc. 35, 795-800.

8 Metz, J. L. and Douglass, J. E. 1959 Soil moisture depletion under several Piedmont cover types. U.S. Dep. Agric. Tech. Bull. 1207, 23 p.

9 Schultz, Richard C. 1979 Tree growth responses to changes in soil moisture, fertility and microorganisms on difficult sites. Proc., Fifth North Am. For. Biology Workshop [Gainesville, Fla., Mar. 13-15, 1978], p. 2-18. School of For. Resour. and Conserv., Univ. Fla., and U.S. Dep. Agric. For. Serv., Southeast. For. Exp. Stn. 430 p.

10 Soil Test Work Group. 1974 Procedures used by State Soil Testing Laboratories in the Southern Region of the United States. South. Coop. Serv. Bull. 190, 23 p.

11 Zahner, R. 1958 Hardwood understory depletes soil water in pine stands. For. Sci. 4, 178-184. 